\title{
Selected properties of organic soils under boreal mire spruce forest in the Romincka Forest, NE Poland
}

\begin{abstract}
The paper presents selected properties of the organic soils developed in boreal mire spruce forests (Sphagno girensohniiPiceetum) in the Romincka Forest (NE Poland). Additionally, the relationship between soil fertility and forest stand productivity was investigated. Data from 12 soil profiles, differing in terms of peatland ecological type (raised bog, transitional bog and fen) was used. The significance of the differences in soil properties among peatland types was assessed with the Kruskal-Wallis test. Soil fertility was described using soil trophic index (SIGo), whereas stand productivity according to site index (SI) value. The properties of the analysed soils varied significantly in terms of peatland type. Soils from fens were more fertile (SIGo 25-31), less acidic ( $\mathrm{pH}>5.7$ ), with lower total potential acidity $\left(36-40 \mathrm{cmol}_{(+)} \cdot \mathrm{kg}^{-1}\right)$, higher base saturation $(77-79 \%), \mathrm{Ca}^{2+}$ content $\left(116-136 \mathrm{cmol}_{(+)} \cdot \mathrm{kg}^{-1}\right)$ and base exchange capacity $\left(123-145 \mathrm{cmol}_{(+)} \cdot \mathrm{kg}^{-1}\right)$ than soils from transition or raised bogs. No significant effect of soil fertility on the site index of stands growing on analysed soils was observed $(r=0.385, \mathrm{p}=0.216)$.
\end{abstract}

Keywords: organic soils, soil properties, Sphagno girensohnii-Piceetum, peatlands

\section{INTRODUCTION}

Boreal mire spruce forests (Sphagno girensohniiPiceetum Polakowski 1962) are a valuable community considered as an important one in terms of biodiversity conservation (Kuusinen 1996, Halvorsen Økland et al. 2003) and carbon sequestration (Turetsky et al. 2010). These ecosystems are typical for peatlands in northern Europe (Maanavilja et al. 2014), but can also be found in Central Europe (Mastny et al. 2016) or in the Mediterranean areas (Kutnar 2000). In Poland, this community occurs only in north-eastern part of the country on sites with decreasing water level, where the transformation of peat soils into the mucky peat soils is a common phenomenon (Matuszkiewicz 2005).

The variability of the forest organic soils properties of is, in general, still poorly recognised, although this knowledge would be crucial e.g. in forest ecosystem monitoring (Laiho et al. 2004, Lasota et al. 2011a, Glina et al. 2016). The relatively small area covered by boreal mire spruce forests in Poland results in a lack of studies on the edaphic conditions of this community. Only Lasota et al. (2011a) refer to this type of forest stands, describing the fertility of soils developed in mixed deciduous (oligotrophic) forests. In turn, Mastny et al. (2016) studied the effect of drainage and water regime restoration on soil organic matter quality and soil microbial activity in boreal mire spruce forests in the Czech Republic.
The objective of the study was to analyse the selected properties of organic soils developed in the boreal mire spruce forests. Additionally, the relationship between soil fertility and site index of the forest stands was analysed.

\section{MATERIAL AND METHODS}

The research was carried out in the Romincka Forest, a rather large forest complex located in northeastern Poland $\left(54.29-54.36^{\circ} \mathrm{N}, 22.33-22.70^{\circ} \mathrm{E}\right)$. Climate conditions of this area belong to the most severe in the country with the exception of the mountain regions (Charakterystyka... 2003). Mean monthly temperature ranges from $-5.5^{\circ} \mathrm{C}$ in January to merely $17^{\circ} \mathrm{C}$ in July. The growing season lasts 190 days on average and is significantly shorter than in other parts of Poland. Mean annual precipitation equals $650 \mathrm{~mm}$, however the differences between years can be substantial. Norway spruce and Scots pine are dominant forest forming species with 40 and 19\% share in the species structure respectively (Charakterystyka... 2003).

Material used in the presented study consists of the data from the soil-habitat works performed for the Gołdap Forest District in accordance with the Instrukcja... (2003). For the study, 12 sites covered by Sphagno girensohnii-Piceetum community were selected. They were located on the raised (sites 1-4) or transitional (sites 5-8) bogs and on the fen 
peatlands (sites 9-12). On each site, the soil profile was dug out and described according to Instrukcja... (2003). Soil samples were collected by genetic soil horizons, single uniform sample per each layer. Physical and chemical soil properties were evaluated according to procedures described by Ostrowska et al. (1991). The $\mathrm{pH}$ was determined potentiometrically in $\mathrm{H}_{2} \mathrm{O}$ and $1 \mathrm{M} \mathrm{KCl}$ with 1:5 soil-to-solvent ratio. Total carbon (TOC) and nitrogen (TN) contents were assessed with CNS 2000 Leco elemental analyser. The content of exchangeable $\mathrm{Ca}^{2+}, \mathrm{Mg}^{2+}, \mathrm{Na}^{+}$and $\mathrm{K}^{+}$ cations was determined in the ammonium acetate extract ( $\mathrm{pH}$ 7.0) with Thermo Scientific iCAP analyser. The total potential acidity (Hh) was assessed with Kappen method in calcium acetate extract. Based on this data, the following parameters were calculated: $\mathrm{C} / \mathrm{N}$ ratio, base exchange capacity (S) as a sum of exchangeable $\mathrm{Ca}^{2+}, \mathrm{Mg}^{2+}, \mathrm{Na}^{+}$, and $\mathrm{K}^{+}$, cation exchange capacity (CEC) as a sum of $\mathrm{Hh}$ and $\mathrm{S}$, and base saturation (BS [\%]) as the S/CEC ratio.

Fertility of the investigated soils was assessed with the soil trophic index for the organic soils (SIGo) calculated according to the procedure described by Brożek et al. (2011). The bulk density (D), which is necessary for SIGo calculation, was determined based on total organic content (TOC) in a given layer, using the following formula: $\mathrm{D}=1.3773 \cdot \mathrm{e}^{-0.0547 \cdot \mathrm{TOC}}$ (Klasyfikacja... 2000). The site index (SI) for the forest stands growing on analysed soils was determined using formulae given by Socha et al. (2015).

As the distribution of the majority of investigated features was different from the normal one (assessment with Shapiro-Wilk test), the significance of the differences between peatland types was evaluated with Kruskal-Wallis test. Statistical calculations were performed using PAST 3.14 software (Hammer et al. 2001).

\section{RESULTS}

Classification of the studied soils according to various systems is presented in table 1. Following the classification used in the forestry practice in Poland (Klasyfikacja... 2000) analysed soils were classified as raised bog peat soils (sites 1-4), transitional bog peat soils (sites 5-8) or fen peat soils (sites 9-12). Application of Polish Soil Classification (Systematyka... 2011) allowed distinguishing peat soil consisted of moderately (sites 1, 2, 6, 5, 7, 8, 12) and slightly (sites $3,4,11$ ) decomposed peat. Only soil profiles 9 and 10 consisted of strongly decomposed (sapric) peat. According to the FAO-WRB (IUSS 2015) classification, investigated soils belonged to Dystric (sites 1-8) and Eutric (sites 9-12) Histosols (Table 1).
TABLE 1. Classification of the analysed soils

\begin{tabular}{llll}
\hline $\begin{array}{l}\text { Site } \\
\text { No. }\end{array}$ & $\begin{array}{l}\text { KGLP } \\
(2000)\end{array}$ & $\begin{array}{l}\text { PSC } \\
(2011)\end{array}$ & FAO-WRB (IUSS 2015) \\
\hline 1 & $\mathrm{Tw}$ & OTet & Dystric Hemic Histosol \\
\hline 2 & $\mathrm{Tw}$ & OTet & Dystric Hemic Histosol \\
\hline 3 & $\mathrm{Tw}$ & OTit & Dystric Fibric Histosol \\
\hline 4 & $\mathrm{Tw}$ & OTit & Dystric Fibric Histosol \\
\hline 5 & $\mathrm{Tp}$ & OTet & Dystric Hemic Histosol \\
\hline 6 & $\mathrm{Tp}$ & OTie & Dystric Epifibric Pantohemic Histosol \\
\hline 7 & $\mathrm{Tp}$ & OTet & Dystric Hemic Histosol \\
\hline 8 & $\mathrm{Tp}$ & OTep & Dystric Hemic Histosol \\
\hline 9 & $\mathrm{Tn}$ & OTat & Eutric Epihemic Pantosapric Histosol \\
\hline 10 & $\mathrm{Tn}$ & OTal & $\begin{array}{l}\text { Eutric Epihemic Amphisapric Histosol } \\
\text { (Endolimnic) }\end{array}$ \\
\hline 11 & $\mathrm{Tn}$ & OTit & Eurtic Fibric Histosol \\
\hline 12 & $\mathrm{Tn}$ & OTet & Eurtic Hemic Histosol \\
\hline
\end{tabular}

$\mathrm{Tw}$ - raised bog soils, $\mathrm{Tp}$ - transitional bog soils, $\mathrm{Tn}$ - fen soils; OTet typical hemic peat soils, OTit - typical fibric peat soils, OTie - hemifibric peat soils, OTep - shallow hemic peat soils, OTat - typical sapric peat soils, OTal - limni-sapric peat soils.

The peat thickness at the study sites ranged from 60 to $160 \mathrm{~cm}$ (Table 2). In general, the horizon boundary was gradual. At the moment of sampling, the ground water table was at the depth of 30-100 cm, $61 \mathrm{~cm}$ on average. The intensive features of gleyic properties were observed in the bottom parts of two profiles, where the mineral bedrock was reached.

The groundcover on raised bog sites was not numerous and constituted of 16-22 species with the dominance of Sphagnum palustre, Vaccinium myrtillus and Lycopodium annotinum. Herbaceous layer on transitional bogs was similar to that of raised bogs in terms of the dominating species as $S$. palustre, $V$. myrtillus, $S$. nemoreum and $S$. recurvum prevailed in the species composition. On the other hand, it was more bio-diversified (21-27 species). Fens characterised the richest groundcover (27-44 species). The herbaceous layer of this peatland type was dominated by Athyrium filixfemina and Oxalis acetosella.

The properties of the investigated soils significantly varied with regard to the peatland type. In general, organic soils within fens turned out to be significantly different from those from transitional and raised bogs (Tables 2 and 3). The lowest $\mathrm{pH}$ values (3.1-4.0) that indicated extreme acidity were observed in profiles from the raised bogs, while the highest (5.7-6.1) in soils from fen peatlands. The TOC content was very variable, but reached similar values for all three analysed peatland types. For raised bogs soils it ranged from 28 to $46 \%$ and for transitional bogs from 20 to $45 \%$, while for fens - from 31 to $46 \%$. An analogous pattern was found for $\mathrm{TN}$ content. The $\mathrm{C} / \mathrm{N}$ ratio values were 
TABLE 2. Selected physical and chemical properties of the analysed soils

\begin{tabular}{|c|c|c|c|c|c|c|c|c|c|}
\hline \multirow{2}{*}{$\begin{array}{l}\text { Site } \\
\text { No. }\end{array}$} & \multirow{2}{*}{$\begin{array}{l}\text { Soil } \\
\text { horizon }\end{array}$} & \multirow{2}{*}{$\begin{array}{l}\text { Depth } \\
\text { (cm) }\end{array}$} & \multirow{2}{*}{$\begin{array}{l}\text { Peat type/ } \\
\text { particle size }\end{array}$} & \multirow{2}{*}{$\begin{array}{l}\text { Soil } \\
\text { moisture }\end{array}$} & \multicolumn{2}{|l|}{$\mathrm{pH}$} & \multirow{2}{*}{$\begin{array}{l}\text { TOC } \\
(\%)\end{array}$} & \multirow{2}{*}{$\begin{array}{l}\mathrm{TN} \\
(\%)\end{array}$} & \multirow[t]{2}{*}{$\mathrm{C} / \mathrm{N}$} \\
\hline & & & & & $\mathrm{H}_{2} \mathrm{O}$ & $\mathrm{KCl}$ & & & \\
\hline \multirow[t]{2}{*}{1} & Oe1 & $0-25$ & hemic & moist & 3.7 & 2.8 & 31.9 & 1.3 & 24.9 \\
\hline & $\mathrm{Oe} 2$ & $25-150$ & hemic & wet & 3.5 & 2.7 & 27.9 & 1.5 & 19.0 \\
\hline \multirow[t]{2}{*}{2} & Oe1 & $0-22$ & hemic & moist & 3.9 & 2.8 & 38.6 & 2.0 & 19.6 \\
\hline & $\mathrm{Oe} 2$ & $22-150$ & hemic & wet & 4.0 & 3.2 & 40.2 & 2.1 & 19.1 \\
\hline \multirow[t]{2}{*}{3} & Oil & $0-35$ & fibric & moist & 3.6 & 2.5 & 39.5 & 1.7 & 23.4 \\
\hline & Oi2 & $35-130$ & fibric & wet & 3.1 & 2.2 & 38.6 & 1.5 & 25.2 \\
\hline \multirow[t]{2}{*}{4} & Oil & $0-45$ & fibric & wet & 3.5 & 2.8 & 45.7 & 1.7 & 27.2 \\
\hline & $\overline{\text { Oi2 }}$ & $45-160$ & fibric & wet & 4.0 & 3.4 & 46.8 & 2.4 & 19.2 \\
\hline \multirow[t]{2}{*}{5} & Oel & $0-35$ & hemic & moist & 4.4 & 2.9 & 41.3 & 2.2 & 18.8 \\
\hline & $\overline{\mathrm{Oe} 2}$ & $35-150$ & hemic & wet & 4.4 & 3.4 & 33.2 & 1.5 & 22.2 \\
\hline \multirow[t]{2}{*}{6} & Oi & $0-35$ & fibric & moist & 4.0 & 3.6 & 45.3 & 2.3 & 19.8 \\
\hline & $\overline{\mathrm{Oe}}$ & $35-150$ & hemic & wet & 4.8 & 3.9 & 41.6 & 2.1 & 20.0 \\
\hline \multirow[t]{2}{*}{7} & Oe1 & $0-33$ & hemic & moist & 4.0 & 2.6 & 34.8 & 1.6 & 21.9 \\
\hline & Oe2 & $33-150$ & hemic & wet & 4.1 & 3.1 & 33.9 & 1.5 & 22.5 \\
\hline \multirow[t]{4}{*}{8} & Oe1 & $0-25$ & hemic & wet & 4.4 & 3.6 & 42.7 & 1.6 & 27.1 \\
\hline & $\mathrm{Oe} 2$ & $25-60$ & hemic & wet & 4.6 & 3.7 & 20.3 & 1.1 & 18.9 \\
\hline & $\mathrm{Cg} 1$ & $60-90$ & pg & wet & - & - & - & - & - \\
\hline & $\mathrm{Cg} 2$ & $90-150$ & $\mathrm{gl}$ & wet & - & - & - & - & - \\
\hline \multirow[t]{2}{*}{9} & $\mathrm{Oe}$ & $0-30$ & hemic & moist & 5.7 & 5.2 & 36.6 & 2.3 & 15.9 \\
\hline & $\mathrm{Oa}$ & $30-150$ & sapric & wet & 5.8 & 5.2 & 36.2 & 2.3 & 16.1 \\
\hline \multirow[t]{4}{*}{10} & $\mathrm{Oe}$ & $0-20$ & hemic & moist & 5.8 & 5.4 & 36.1 & 2.2 & 16.4 \\
\hline & $\mathrm{Oa}$ & $20-80$ & sapric & wet & 5.9 & 5.2 & 37.5 & 2.1 & 18.0 \\
\hline & $\mathrm{Lc}$ & $80-100$ & gy & wet & - & - & - & - & - \\
\hline & $\mathrm{Cg}$ & $100-150$ & $\mathrm{iz}$ & wet & - & - & - & - & - \\
\hline \multirow[t]{2}{*}{11} & Oil & $0-35$ & fibric & wet & 5.7 & 5.3 & 45.9 & 2.0 & 23.5 \\
\hline & Oi2 & $35-160$ & fibric & wet & 5.7 & 5.4 & 31.3 & 2.0 & 15.3 \\
\hline \multirow[t]{2}{*}{12} & Oe1 & $0-35$ & hemic & wet & 6.0 & 5.2 & 39.1 & 2.1 & 16.2 \\
\hline & $\overline{\mathrm{Oe} 2}$ & $35-160$ & hemic & wet & 6.1 & 5.1 & 40.3 & 2.0 & 20.2 \\
\hline
\end{tabular}

iz - clay, pg - loamy sand, gl - sandy loam, gy - gyttia.

rather similar regardless of the peatland type with slightly lower values observed for fens (16-20 vs 19-27). The lowest total potential acidity $(<45$ $\mathrm{cmol}_{(+)} \cdot \mathrm{kg}^{-1}$ ) was found for fen soils, while the highest $\left(>140 \mathrm{cmol}_{(+)} \cdot \mathrm{kg}^{-1}\right)$ was for raised bogs. No significant difference among peatland types occurred as far as the potassium content is concerned. In case of sodium, slightly higher values were recorded for raised bog soils $\left(0.21-0.60 \mathrm{cmol}_{(+)} \cdot \mathrm{kg}^{-1}\right.$ vs $0.03-0.45$ and $\left.0.20-0.38 \mathrm{cmol}_{(+)} \cdot \mathrm{kg}^{-1}\right)$. For both calcium and magnesium content, the analysed soils differed significantly with peatland type with the lowest values found for raised bogs, while the highest for fens (Table 3). Base exchange capacity and base saturation of the investigated soils were related to the peatland type as well. And again, the lowest values were found for raised bogs, while the highest for fens: $7-47$ vs $88-170 \mathrm{cmol}_{(+)} \cdot \mathrm{kg}^{-1}$ for $\mathrm{S}$ and $5-31$ vs $72-82 \%$ for BS. In turn, CEC, which is the sum of $\mathrm{S}$ and $\mathrm{Hh}$, was at the similar level for all soils.

Soil fertility described with SIGo index (Table 4) was not a very variable property of the investigated soils (coefficient of variation $=15 \%$ ). Average values of SIGo varied significantly with regard to the peatland type $(p=0.006)$. The highest SIGo values were observed for fens (25-31), whereas the lowest for the profiles located on raised bogs (19-24). In turn, site index calculated for the stands growing on analysed soils showed no dependence on the peatland type $(p=0.325)$. The highest values were observed for stands on fens $(25.7-31.8 \mathrm{~m})$ and transitional bogs $(25.9-30.3 \mathrm{~m})$, while the lowest for the raised bogs (25.9-27.6 m) 
TABLE 3. Sorption properties of the organic horizons in the analyzed soils

\begin{tabular}{|c|c|c|c|c|c|c|c|c|c|}
\hline \multirow{2}{*}{$\begin{array}{l}\text { Site } \\
\text { No. }\end{array}$} & \multirow{2}{*}{$\begin{array}{l}\text { Soil } \\
\text { horizon }\end{array}$} & $\mathrm{Hh}$ & $\mathrm{K}^{+}$ & $\mathrm{Na}^{+}$ & $\mathrm{Ca}^{2+}$ & $\mathrm{Mg}^{2+}$ & $\mathrm{S}$ & $\mathrm{CEC}$ & \multirow{2}{*}{$\begin{array}{l}\text { BS } \\
(\%)\end{array}$} \\
\hline & & \multicolumn{7}{|c|}{$\overline{\left(\mathrm{cmol}_{(+)} \cdot \mathrm{kg}^{-1}\right)}$} & \\
\hline \multirow[t]{2}{*}{1} & Oe1 & 163.2 & 0.38 & 0.60 & 21.2 & 3.3 & 25.5 & 188.7 & 13.5 \\
\hline & Oe 2 & 73.8 & 0.13 & 0.43 & 25.3 & 3.7 & 29.5 & 103.3 & 28.6 \\
\hline \multirow[t]{2}{*}{2} & Oe1 & 153.6 & 0.05 & 0.36 & 25.1 & 3.2 & 28.7 & 182.3 & 15.7 \\
\hline & $\overline{\mathrm{Oe} 2}$ & 138.6 & 0.12 & 0.27 & 42.5 & 4.2 & 47.1 & 185.7 & 25.4 \\
\hline \multirow[t]{2}{*}{3} & Oil & 144.6 & 0.65 & 0.29 & 4.8 & 1.2 & 7.0 & 151.6 & 4.6 \\
\hline & Oi2 & 171.6 & 0.32 & 0.31 & 8.9 & 1.9 & 11.4 & 183.0 & 6.3 \\
\hline \multirow[t]{2}{*}{4} & Oil & 195.0 & 0.45 & 0.40 & 20.8 & 1.9 & 23.6 & 218.6 & 10.8 \\
\hline & Oi2 & 74.4 & 0.14 & 0.21 & 32.0 & 1.9 & 34.2 & 108.6 & 31.5 \\
\hline \multirow[t]{2}{*}{5} & Oe1 & 106.8 & 0.37 & 0.37 & 39.5 & 4.8 & 45.1 & 151.9 & 29.7 \\
\hline & Oe2 & 116.4 & 0.12 & 0.25 & 52.8 & 6.8 & 60.0 & 176.4 & 34.0 \\
\hline \multirow[t]{2}{*}{6} & Oi & 91.8 & 0.26 & 0.03 & 59.5 & 4.5 & 64.3 & 156.1 & 41.2 \\
\hline & $\mathrm{Oe}$ & 82.2 & 0.07 & 0.03 & 78.1 & 5.7 & 83.9 & 166.1 & 50.5 \\
\hline \multirow[t]{2}{*}{7} & Oe1 & 177.6 & 0.28 & 0.36 & 25.6 & 3.5 & 29.7 & 207.3 & 14.3 \\
\hline & Oe2 & 139.2 & 0.11 & 0.24 & 35.9 & 5.4 & 41.6 & 180.8 & 23.0 \\
\hline \multirow[t]{2}{*}{8} & Oe1 & 105.0 & 0.45 & 0.45 & 13.0 & 2.4 & 16.0 & 121.0 & 13.2 \\
\hline & Oe2 & 49.8 & 0.12 & 0.12 & 12.6 & 1.4 & 14.2 & 64.0 & 22.2 \\
\hline \multirow[t]{2}{*}{9} & $\mathrm{Oe}$ & 38.4 & 0.37 & 0.21 & 125.0 & 11.8 & 137.3 & 175.7 & 78.2 \\
\hline & $\mathrm{Oa}$ & 39.6 & 0.16 & 0.20 & 156.9 & 13.3 & 170.5 & 210.1 & 81.2 \\
\hline \multirow[t]{2}{*}{10} & $\mathrm{Oe}$ & 33.6 & 0.27 & 0.27 & 80.1 & 7.5 & 88.1 & 121.7 & 72.4 \\
\hline & $\mathrm{Oa}$ & 35.7 & 0.10 & 0.39 & 118.2 & 12.1 & 130.8 & 166.5 & 78.6 \\
\hline \multirow[t]{2}{*}{11} & Oi & 31.2 & 0.30 & 0.21 & 140.3 & 4.7 & 145.5 & 176.7 & 82.3 \\
\hline & Oi & 36.6 & 0.20 & 0.16 & 130.7 & 5.2 & 136.2 & 172.9 & 78.8 \\
\hline \multirow[t]{2}{*}{12} & $\mathrm{Oe}$ & 40.8 & 0.06 & 0.32 & 118.2 & 4.2 & 122.8 & 163.6 & 75.1 \\
\hline & $\mathrm{Oe}$ & 46.2 & 0.01 & 0.33 & 138.7 & 4.9 & 143.9 & 190.1 & 75.7 \\
\hline
\end{tabular}

TABLE 4. Components used in calculation of the soil trophic index (SIGo) and site index (SI) of forest stands

\begin{tabular}{|c|c|c|c|c|c|c|c|c|c|c|}
\hline \multirow{2}{*}{$\begin{array}{l}\text { Profile } \\
\text { No. }\end{array}$} & \multicolumn{2}{|l|}{$\mathrm{rHh}$} & \multicolumn{2}{|l|}{$\mathrm{rTN}$} & \multicolumn{2}{|l|}{$\mathrm{S}$} & \multirow[t]{2}{*}{ SIGo } & \multirow{2}{*}{$\begin{array}{l}\text { Age } \\
\text { (yrs) }\end{array}$} & \multirow{2}{*}{$\begin{array}{l}\text { Height } \\
\text { (m) }\end{array}$} & \multirow{2}{*}{$\begin{array}{l}\text { SI } \\
(\mathrm{m})\end{array}$} \\
\hline & value & index & value & index & value & index & & & & \\
\hline 1 & 3.74 & 1 & 0.0052 & 5 & 126 & 9 & 20 & 140 & 32 & 27.6 \\
\hline 2 & 3.28 & 1 & 0.0101 & 8 & 103 & 9 & 24 & 130 & 31 & 27.5 \\
\hline 3 & 4.10 & 1 & 0.0072 & 6 & 26 & 7 & 19 & 100 & 26 & 26.0 \\
\hline 4 & 1.83 & 1 & 0.0062 & 5 & 50 & 8 & 19 & 101 & 26 & 25.9 \\
\hline 5 & 3.54 & 1 & 0.0117 & 8 & 177 & 9 & 24 & 97 & 29 & 29.5 \\
\hline 6 & 3.54 & 1 & 0.0117 & 8 & 177 & 9 & 24 & 97 & 29 & 29.5 \\
\hline 7 & 1.55 & 1 & 0.0073 & 6 & 125 & 9 & 21 & 120 & 33 & 30.3 \\
\hline 8 & 1.63 & 1 & 0.0058 & 5 & 66 & 9 & 20 & 81 & 23 & 25.9 \\
\hline 9 & 0.51 & 6 & 0.0134 & 8 & 173 & 9 & 31 & 90 & 30 & 31.8 \\
\hline 10 & 1.12 & 2 & 0.0145 & 8 & 465 & 10 & 27 & 90 & 26 & 27.0 \\
\hline 11 & 1.17 & 2 & 0.0083 & 7 & 446 & 10 & 25 & 130 & 29 & 25.7 \\
\hline 12 & 1.04 & 3 & 0.0130 & 8 & 321 & 9 & 27 & 110 & 32 & 30.5 \\
\hline
\end{tabular}

Explanation: $\mathrm{S}$ - base cations resources, $\mathrm{rHh}$ - recalculated total potential acidity, $\mathrm{rTN}$ - recalculated nitrogen content. 
(Table 4). Although SI increased along with the SIGo values, no significant influence of soil fertility on this measure of stand productivity was found $(\mathrm{r}=0.385$, $\mathrm{p}=0.216)$.

\section{DISCUSSION}

Boreal mire spruce forest (Sphagno girensohniiPiceetum Polakowski 1962) occurs in general in two variants that differ both in species composition and structure as well as soil properties (Matuszkiewicz 2005). The typical, oligotrophic variant (Sphagno girgensohnii-Piceetum myrtilletosum) is related to large meltwater basins filled with peat deposits. On such sites, the edaphic conditions decrease significantly towards the centre of the bog (lower fertility, higher acidity). The forest floor is covered by Vaccinium myrtillus, $V$. vitis-idaea, Lycopodium annotinum and Oxalis acetosella, Majanthemum bifolium and Trientalis europaea. Mesotrophic, fern variant (Sphagno girgensohnii-Piceetum thelypteridetosum) usually occurs on fens and more fertile transitional bogs located in areas included in the run-off system (e.g. bogged river terraces, peatlands between adjoining lakes). The list of species specific for this variant includes Viola palustris, Carex nigra, or C. echinata. More favourable edaphic conditions result in the presence of Chrysosplenium alternifolium, Mycelis muralis or Athyrium filixfemina. The above mentioned specific species were found on the study sites, so the community identification based on the floristic data was proper.

The abundance of a given species in the vegetation cover of analysed peatlands affects soil properties. The dominance of Norway spruce contributes to increased soil acidity and exchangeable aluminium concentration (Gruba et al. 2013). This affects soil microbiological activity (Błońska et al. 2013) as well as the sorption complex (Gałka et al. 2013) and nutrients resources (Szopka et al. 2010). As presented by Gałka et al. (2014), soils under Norway spruce stands have a higher organic carbon pool in upper horizons and are characterised by increased activity of exchangeable aluminium. On the other hand, such soils have rather low $\mathrm{pH}$ and base exchange cations content, as well as low loads of available potassium and magnesium. All those features result in lower values of the trophic index (Gałka et al. 2014). Also the composition of herbaceous layer is an important factor that influences soil properties. As reported by Parzych (2015) various moss species differ with respect to nutrient accumulation capacity, hence the peat that develops from decomposing plants differs in property.
The studied soils showed great similarity to those described by Lasota et al. (2011a). Total carbon content reported by these Authors varied from 37 to $47 \%$, whereas in current research this range is a bit wider (32-47\%). Mastny et al. (2016) recorded 42-47\% carbon in their analyses. Total nitrogen content in investigated soils is similar to the findings from the Czech Republic (Mastny et al. 2016) and less variable than values reported by Lasota et al. (2011a). In general, analysed soils have more nutrients than on the other sites in the Romincka Forest (Lasota et al. 2011a). The base exchange capacity was higher for both soils on the raised bogs and the fens (6-14 vs. 7-23 and $120-123$ vs. $137-180 \mathrm{cmol}_{(+)} \cdot \mathrm{kg}^{-1}$, respectively). Also SIGo values are higher for investigated profiles than for those described by Lasota et al. (2011a).

Based on the obtained SIGo values (Table 3) and thresholds proposed by Lasota et al. (2011b), forest site types on sites 1-8 can be classified as bog mixed coniferous forests $(\mathrm{BMb})$, whereas on sites 9-12 as bog mixed deciduous forests (LMb). Such evaluation stays in accordance with the habitat classification used in Polish forestry (Instrukcja... 2003). In this classification, the oligotrophic variant of boreal mire spruce forest is assigned to $\mathrm{BMb}$, while the mesotrophic to $\mathrm{LMb}$. This classification is also supported by the species composition of herbaceous layer, which on the investigated sites is typical for these habitats.

The presented study showed no significant effect of soil fertility on the site index of Norway spruce, with the opposite relationship found by Gömöryova and Gömöry (1995), Bošela et al. (2013) or Lasota et al. (2016). However, these authors studied mineral not the organic soils. Lasota et al. (2016) report significant impact of the $\mathrm{Al}^{3+} /$ effective cation exchange capacity ratio, as well as carbon and potassium content on the site index of Norway spruce in the Sudety Mts. Gömöryova and Gömöry (1995) also found a relationship between soil edaphic factors and productivity measures of this species.

\section{CONCLUSIONS}

1. Organic soils under boreal mire spruce forest (Sphagno girensohnii-Piceetum) in the Romincka Forest varied significantly in terms of chemical properties, fertility and peatland type.

2. Fen peat soils consisted of the sapric peat and characterised with the highest $\mathrm{pH}$, carbon content, base exchange capacity and base saturation. In turn soils from the raised bogs had the highest total potential acidity, while those from the transition bogs stood out in terms of the cation exchange capacity. 
3. No significant effect of the fertility of the analysed organic soils on the site index of Norway spruce stands was observed.

\section{ACKNOWLEDGEMENTS}

Author is grateful to two anonymous reviewers whose comments and remarks contributed to raising the quality of the paper substantially. Bartłomiej Glina (Poznań University of Life Sciences, Poland) helped with WRB classification.

\section{REFERENCES}

Błońska E., Lasota J., Januszek K., 2013. Variability of enzymatic activity in forest Cambisols and Brunic Arenosols of Polish lowland areas. Soil Science Annual 64(2): 54-59.

Bošela M., Mališ F., Kulla L., Šeben V., Deckmyn G., 2013. Ecologically based height growth model and derived raster maps of Norway spruce site index in the Western Carpathians. European Journal of Forest Research 132: 691-705.

Brożek S., Zwydak M., Lasota J., Różański W., 2011. Założenia metodyczne badań związków między glebą a zespołami roślinnymi w lasach. Roczniki Gleboznawcze-Soil Science Annual 62(4): 16-38 (in Polish with English summary).

Charakterystyka gleb i siedlisk Nadleśnictwa Gołdap, 2003. Biuro Urządzania Lasu i Geodezji Leśnej, Oddział w Białymstoku (in Polish).

Gałka B., Podlaska M., Kabała C., 2013. Siedliskotwórcze właściwości gleb brunatnych kwaśnych wytworzonych z granitoidów w Górach Stołowych. Sylwan 157(5): 385-394 (in Polish with English summary).

Gałka B., Kabała C., Łabaz B., Bogacz A., 2014. Wpływ drzewostanów o zróżnicowanym udziale świerka na gleby różnych typów siedliskowych lasu w Górach Stołowych. Sylwan 158(9): 684-694 (in Polish with English summary).

Glina B., Bogacz, A., Gulyás M., Zawieja B., Gajewski P., Kaczmarek Z., 2016. The effect of long-term forestry drainage on the current state of peatland soils: A case study from the Central Sudetes (SW Poland). Mires and Peat 18(21): 1-11.

Gömöryova E., Gömöry D., 1995. Relationships between environmental factors and height growth and yield of Norway spruce stands: a factor-analytic approach. Forestry 68(2): 145-152.

Gruba P., Mulder J., Brożek S., 2013. Modelling the pH dependency of dissolved calcium and aluminium in $\mathrm{O}, \mathrm{A}$ and $\mathrm{B}$ horizons of acid forest soils. Geoderma 206: 85-91.

Halvorsen Økland R., Rydgren K., Økland T., 2003. Plant species composition of boreal spruce swamp forests: closed doors and windows of opportunity. Ecology 84: 1909-1919.

Hammer Ø., Harper D.A.T., Ryan P.D., 2001. PAST: Paleontological statistics software package for education and data analysis. Palaeontologia Electronica 4 (1).

Instrukcja wyróżniania i kartowania siedlisk leśnych, 2003. Dyrekcja Generalna Lasów Państwowych, Warszawa (in Polish).

IUSS Working Group WRB, 2015. World reference base for soil resources 2014, update 2015. International Soil Classification System for Naming Soil and Creating Legends for Soil Maps. Food and Agriculture Organization of the United Nations, Rome. pp. 190.
Klasyfikacja gleb leśnych Polski (Classification of forest soils in Poland). 2000. CILP. pp. 122 (in Polish).

Kutnar L., 2000. Spruce mire types on the Pokljuka plateau, Slovenia. Phyton 40(4): 123-128.

Kuusinen M., 1996. Importance of spruce swamp-forests for epiphyte diversity and flora on Picea abies in southern and middle boreal Finland. Ecography 19: 41-51.

Laiho R., Penttilä T., Laine J., 2004. Variation in soil nutrient concentrations and bulk density within peatland forest sites. Silva Fennica 38(1): 29-41.

Lasota J., Zwydak M., Wanic T., Brożek S., 2011a. Różnorodność gleb zespołów borów mieszanych. Roczniki Gleboznawcze - Soil Science Annual 62(4): 54-73 (in Polish with English summary).

Lasota J., Brożek S., Zwydak M., 2011b. Zastosowanie siedliskowego indeksu glebowego (SIG) w projektowaniu składu gatunkowego odnawianych lasów. Roczniki Gleboznawcze Soil Science Annual 62(4): 150-163 (in Polish with English summary).

Lasota J., Błońska E., Zwydak M., 2016. Relations between Site Characteristics and Spruce Stand Productivity. Baltic Forestry 22(1): 81-89.

Maanavilja L., Aapala K., Haapalehto T., Kotiaho J.S., Tuittila E., 2014. Impact of drainage and hydrological restoration on vegetation structure in boreal spruce swamp forests. Forest Ecology and Management 330: 115-125.

Mastný J., Urbanová Z., Kaštovská E., Straková P., Šantrůčková H., Edwards K.R., Picek T., 2016. Soil organic matter quality and microbial activities in spruce swamp forests affected by drainage and water regime restoration. Soil Use and Management 32: 200-209.

Matuszkiewicz J.M., 2005. Zespoły leśne Polski. Wyd. Naukowe PWN. p. 340 (in Polish).

Ostrowska A., Gawliński S., Szczubiałka Z., 1991. Metody analizy i oceny właściwości gleb i roślin. Katalog. Instytut Ochrony Środowiska, Warszawa. p. 334 (in Polish).

Parzych A., 2015. Akumulacja makro- i mikroelementów w mchach Słowińskiego Parku Narodowego. Sylwan 159(4): 345-352 (in Polish with English summary).

Socha J., Ochał W., Grabczyński S., Maj M., 2015. Modele bonitacyjne dla gatunków lasotwórczych Polski opracowane na podstawie tablic zasobności. Sylwan 159(8): 639-649 (in Polish with English summary).

Szopka K., Kabała C., Karczewska A., Bogacz A., Jezierski P., 2010. Pools of available nutrients in soils from different altitudinal forest zones located in a monitoring system of the Karkonosze Mountains National Park, Poland. Polish Journal of Soil Science 43(2): 173-188.

Systematyka gleb Polski (Polish soil classification), 2011. Roczniki Gleboznawcze - Soil Science Annual 62(3): 1-193 (in Polish).

Turetsky M.R., Mack M.C., Hollingsworth T.N., Harden J.W., 2010. The role of mosses in ecosystem succession and function in Alaska's boreal forest. Canadian Journal of Forest Research 40: 1237-1264.

Received: June 12, 2016

Accepted: December 18, 2017

Associated editor: J. Lasota 


\section{Wybrane właściwości gleb organicznych borealnych świerczyn bagiennych Puszczy Rominckiej (NE Polska)}

Streszczenie: W pracy przedstawiono wybrane właściwości gleb organicznych borealnych świerczyn bagiennych (Sphagno girensohnii-Piceetum) z Puszczy Rominckiej (NE Polska). Ponadto zbadano zależność między żyznością gleby a produkcyjnością drzewostanów. Wykorzystano dane z 12 profili glebowych zlokalizowanych na torfowiskach różnego typu (wysokie, przejściowe i niskie). Istotność różnic we właściwościach gleby z różnych rodzajów torfowisk oceniono za pomocą testu Kruskala-Wallisa. Żyzność gleby opisywano przy użyciu siedliskowego indeksu glebowego dla gleb organicznych (SIGo), natomiast produkcyjność drzewostanu za pomocą bonitacji wzrostowej (SI). Właściwości analizowanych gleb różniły się istotnie w zależności od rodzaju torfowiska. Gleby z torfowisk niskich były bardziej żyzne (SIGo 25-31), mniej kwaśne (pH> 5,7) o mniejszej potencjalnej kwasowości (36-40 $\left.\mathrm{cmol}_{(+)} \cdot \mathrm{kg}^{-1}\right)$, wyższym stopniu wysycenia zasadami (77-79\%), zawartości Ca ${ }^{2+}\left(116-136 \mathrm{cmol}_{(+)} \cdot \mathrm{kg}^{-1}\right)$ i pojemności sorpcyjnej $\left(123-145 \mathrm{cmol}_{(+)} \cdot \mathrm{kg}^{-1}\right)$ niż gleby torfowisk przejściowych i wysokich. Nie zaobserwowano istotnego wpływu żyzności gleby na bonitację wzrostową drzewostanów rosnących na analizowanych glebach $(\mathrm{r}=0,385, \mathrm{p}=0,216)$.

Słowa kluczowe: gleby organiczne, właściwości gleb, Sphagno girensohnii-Piceetum, torfowiska 